\title{
AMAR
}

AMAR (Andalas Management Review)

Vol. 4, No.2 (2020) 73-88

The Management Institute, Faculty of Economics, Universitas Andalas ISSN (Print) 2476-9282 | ISSN (Online) 2548-155X

\section{Market Testing dan Positioning Produk Inovasi}

\author{
Berri Brilliant Albara, Mayang Larasati, Sapta Eka Putra \\ aDepartment of Management Faculty of Economics Universitas Andalas,, \\ berribrilliantalbar@eb.unand.ac.id
}

\begin{abstract}
The product innovation enters the next stage in the product development process series towards commercialization. As a product during its development period, it is necessary to carry out market research to determine consumer preferences and perceptions, to become the basis for business analysis and improvement. This activity is carried out through deep interviews with inventors, product/sample tests and simulations, surveys and observations on the market and its segmentation. Market research techniques are used by searching, gathering, and analyzing information about consumers or markets that are appropriate for the business they run. In addition to product quality through understanding the needs and tastes of consumers, another thing that also builds consumer ratings of products is perception. Positioning is the initial analysis to build perception in the minds of consumers. This activity aims to obtain market research documents to determine consumer perceptions about innovation products after consuming the product so that it can be used as a reference for product improvement before commercialization. This activity also aims to help to analyze positioning and design marketing strategies for the next stage. Understanding consumer needs and creating products that are able to meet the needs and solve consumer problems are the keys to successful product commercialization. This activity carried out market research on 7 Andalas University innovation products on food and beverage category with 100 respondents for each of their products spread across the West Sumatra region. This activity produces product market research documents that can be used by each inventor and developer of each product to develop and commercialize their products.
\end{abstract}

Keywords: Innovation, Market Research, Perception, Positioning

\section{PENDAHULUAN}

Konsumen merupakan dasar utama dalam perencanaan dan pengembangan produk baru. Memahami kebutuhan konsumen dan menciptakan produk yang mampu memenuhi kebutuhan dan menyelesaikan masalah konsumen adalah kunci suksesnya komersialisasi produk. Pemasaran modern adalah pemasaran yang berorientasi pada konsumen. Oleh karenanya diperlukan Manajemen pemasaran yang lebih kompleks, salah satunya dengan riset pasar. Riset pasar dalam memulai suatu bisnis diperlukan sebelum melakukan komersialisasi. Teknik riset pasar digunakan oleh calon pengusaha maupun pengusaha yang telah berjalan supaya bisnisnya lebih berkembang dengan cara mencari, mengumpulkan, dan menganalisa informasi tentang konsumen atau pasar yang sesuai dengan usaha yang mereka 
jalankan. Salah satu bentuk riset pasar adalah market testing, pengujian produk langsung pada konsumen sebagai satu langkah terakhir sebelum komersialisasi.

Selain kualitas produk melalui pemahaman kebutuhan dan selera konsumen, hal lain yang juga membangun penilaian konsumen terhadap produk adalah persepsi. Positioning merupakan analisa awal untuk membangun persepsi di benak konsumen. Positioning adalah dasar untuk merancang produk dan bauran pemasaran agar dapat tercipta kesan tertentu di ingatan konsumen. Sehingga, konsumen memahami dan menghargai apa yang dilakukan perusahaan dalam membangun value produknya.

\subsection{Tujuan}

1. Mengetahui penilaian calon konsumen mengenai produk-produk inovasi.

2. Mengetahui positioning produk-produk inovasi.

\subsection{Tinjauan Pustaka}

Inovasi adalah pengelolaan seluruh aktifitas yang melibatkan proses pencarian ide, pengembangan teknologi, manufacturing, dan pemasaran sebuah produk atau proses yang baru atau yang ditingkatkan (Trout, 2005). Dalam perkembangannya kerangka inovasi dapat melibatkan ilmu pengetahuan, teknologi, dan kebutuhan pasar.

Innovation $=$ theoretical conception + technical invention + commercial exploitation

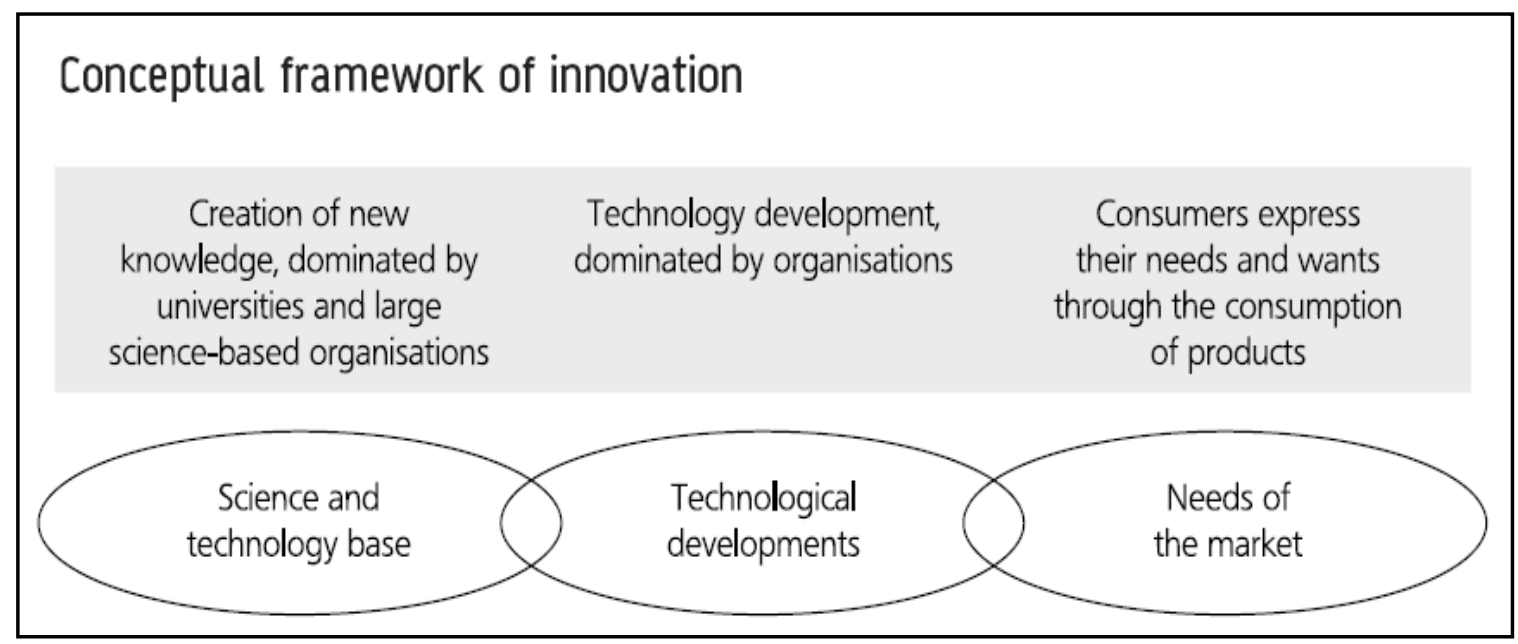

Gambar 1. Konsep kerangka inovasi

Source: Trout (2005)

Produk inovasi di dalam penelitian ini tergolong dalam produk improvements dan modifications. Produk tersebut merupakan perbaikan dari produk-produk yang telah ada dan penambahan manfaat-manfaat baru. Pengembangan produk baru dapat dilakukan melalui delapan tahap. (Kotler dan Keller, 2016), yaitu: 
a. Penciptaan ide. Ide timbul dari berbagai hasil penelitian yang dilakukan, salah satunya di lingkungan universitas.

b. Penyaringan ide. Berbagai ide tersebut dipilih sesuai dengan kebutuhan dan kriteria tertentu

c. Pengembangan konsep dan pengujian. Prototype produk diciptakan dan mulai dilakukan percobaan

d. Pengembangan strategi pemasaran.

e. Analisis bisnis. Penghitungan berbagai aspek biaya dan peramalan permintaan untuk menakar keberlangsungan produk.

f. Pengembangan produk. Dalam proses ini dikembangkan produk dan strategi pemasaran untuk komersialisasi nantinya.

g. Pengujian pasar/ riset pasar. Melakukan pengujian pada pasar ril atau pasar yang disimulasikan. Kegiatan ini dapat berupa:

1) Riset gelombang penjualan: menawarkan contoh produk gratis kepada konsumen

2) Uji tersimulasi: mensimulasi pemilihan produk, menilai dan mewanwancarai konsumen

3) Uji terkendali: menguji pada lingkungan nyata yang dikondisikan

Pada tahap ini inventor produk dihadapkan pada pilihan apakah akan melanjutkan ke tahap selanjutnya yaitu komersialisasi, atau perlu melakukan perbaikan dan kembali mundur ke tahap pengmbangan produk. Dengan perbaikan diharapkan produk akan lebih siap untuk dikomersilkan.

h. Komersialisasi. Memasarkan produk kepada konsumen. Dalam tahap komersialisasi nantinya riset pasar dan pengembangan produk dapat terus dilakukan demi memuhi kebutuhan konsumen. 


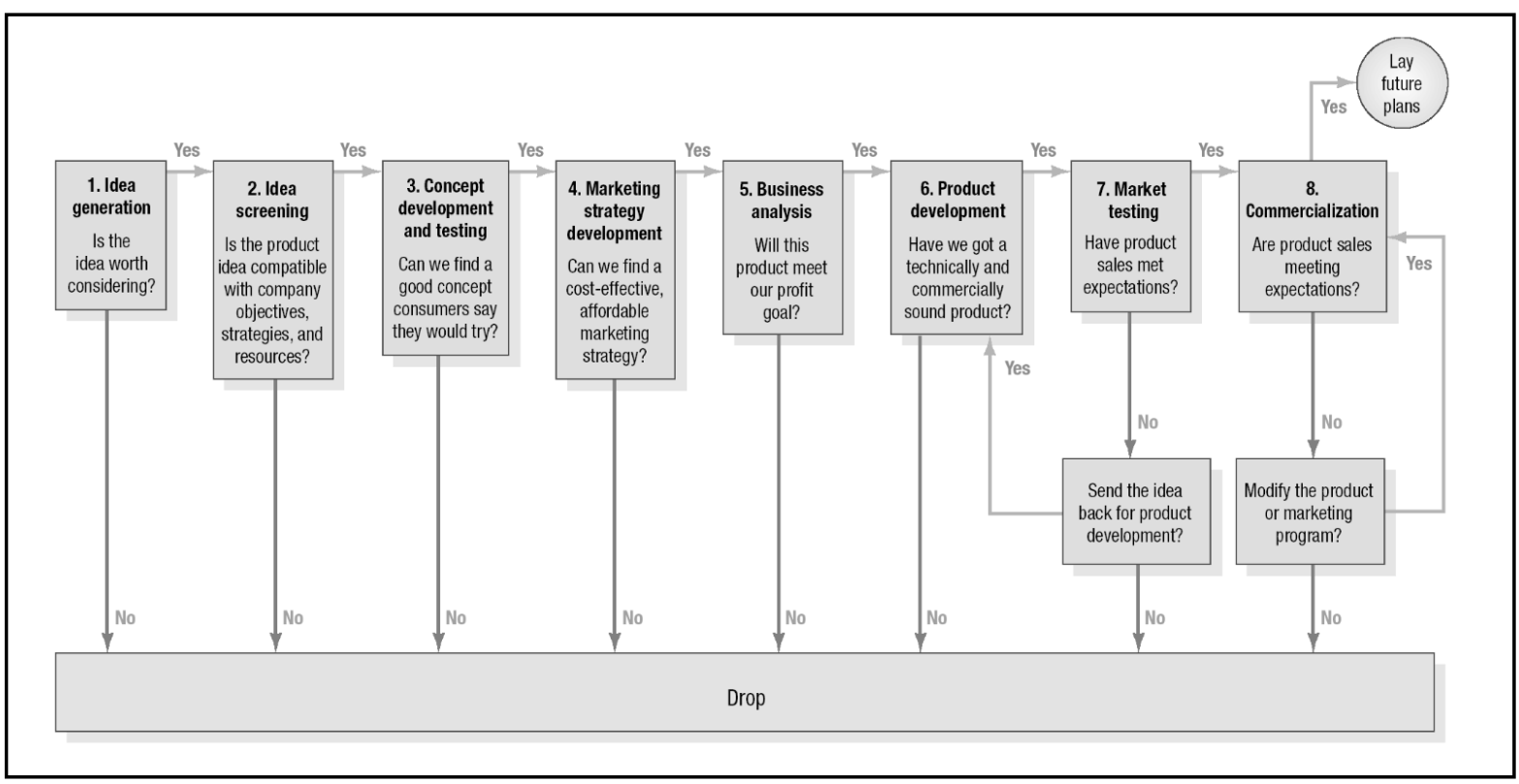

Gambar 2. Alur Pengembangan Produk Baru Kotler dan Keller, (2016)

Positioning adalah aktifitas membentuk dan mengomunikasikan manfaat utama yang membedakan produk dalam pasar untuk menanamkan produk dalam ingatan konsumen/target pasar (Kotler dan Keller, 2016). Dalam menciptakan positioning produk dapat dilakukan dengan menganalisa Point of Parity (POP) dan Point of Difference (POD). Positioning selanjutnya menjadi dasar penyusunan strategi pemasaran, salahsatunya dengan diungkapkan melalui suatu pernyataan (positioning statement).

Titik kesamaan (point of parity), adalah asosiasi-asosiasi yang tidak harus unik untuk merek tetapi dapat dimiliki bersama dengan merek lain Jenis asosiasi ini mempunyai dua bentuk dasar:

a. Titik kesamaan kategori adalah asosiasi-asosiasi yang dipandang esensial oleh konsumen untuk suatu penawaran yang sah dan kredibel dalam kategori produk atau jasa tertentu.

b. Titik kesamaan pesaing adalah asosiasi yang dirancang untuk menegaskan titik perbedaan pesaing.

Titik perbedaan (point of difference) adalah atribut atau manfaat yang secara kuat diasosiasikan konsumen dengan suatu merek, dinilai positif, dan diyakini tidak ditemukan 
kesamaannya pada merek pesaing. POD menunjukkan keunggulan dari sebuah merek. Ada tiga keinginan utama konsumen akan titik perbedaan:

a. Relevansi, konsumen sasaran harus merasa bahwa POD itu penting dan relevan secara pribadi

b. Lain dari yang lain, konsumen harus menemukan bahwa titik perbedaan itu memang lain daripada yang lain dan unggul.

c. Dapat dipercaya, keunggulan yang diposisikan dapat dipercaya konsumen.

\section{METODOLOGI}

Penelitian ini menggunakan desain deskriptif eksploratif yang bertujuan untuk menggambarkan suatu fenomena, menerjemahkan data secara sistematis sehingga dapat lebih mudah dipahami dan diambil manfaatnya. Pengumpulan data dilakukan melalui wawancara, uji produk, observasi dan survey melalui kuesioner di wilayah Sumatera Barat. Objek penelitian ini berupa 7 produk hasil inovasi Universitas Andalas pada kategori food and baverage, yaitu: cookies kopi, cookies sorgum, crackers daun murbei, frozen yoghurt, kopi kulit manggis, teh kulit manggis, dan teh daun gambir. Uji produk dilakukan dengan menyajikan dalam kondisi penyajian yang sesuai (diseduh panas, dingin, dalam suhu kamar, kering, dan lainnya) dan diberikan kepada calon konsumen agar dapat dicoba dan diberikan penilaian. Kuesioner untuk menilai tentang produk, tampilan dan kualitas kemasan, harga, rasa, dan minat beli diberikan secara langsung yang berisi pertanyaan kepada calon konsumen (yang telah mencoba produk), pengisian kuesioner dilakukan pada 100 responden pada masingmasing produk.

\section{HASIL DAN DISKUSI}

Berikut hasil uji pasar yang berisi persepsi konsumen pada komponen produk dan positioning, serta saran perbaikan produk.

\subsection{Cookies Kopi}

a. Kemasan Produk berbentuk tabung dengan bahan mika bening. Kemasan sudah memenuhi standar kemasan cookies dengan rata-rata skor 6.9 (dari skala 10) dan mayoritas dinilai biasa baik secara estetika maupun secara fungsi sebagai pelindung makanan. Calon konsumen menyarankan agar kemasan diberi label yang menarik dan keterangan produk. 
b. Harga produk Rp. 20.000,-/tabung. Calon konsumen dengan berbagai tingkat pendapatan berpendapat harga dan kuantitas produk sesuai serta tidak murah. Bagi calon konsumen yang menggunakan uang jajan mayoritas menganggap harga produk sesuai. Namun bagi calon konsumen kelas bawah, harga dirasakan agak mahal. Harga produk dirasakan cocok bagi segmentasi pasar pelajar/mahasiswa yang menggunakan uang jajan, dan juga sesuai bagi kalangan berpenghasilan diatas UMR serta menengah ke atas.

c. Rasa kopi khas "kopi premium lokal" dinilai positif oleh calon konsumen, dengan mayoritas calon konsumen berpendapat rasa cookies ini enak dengan nilai akhir 7.2 dari skala 10. Calon konsumen laki-laki maupun perempuan memiliki pendapat yang hampir sama dimana mayoritas menilai rasa cookies enak. Melalui wawancara lebih lanjut, calon konsumen menilai rasa agak pahit khas kopi dan perlu diberi sedikit rasa manis agar lebih enak.

d. Minat beli jika produk dikomersilkan nantinya. Dengan penilaian terhadap merek, kemasan, rasa, dan harga saat ini mayoritas calon konsumen berminat untuk membeli Cookies Kopi bila dijual nantinya. Jika mengacu pada bias dan toleransi jawaban konsumen sebesar 10\%, maka minat beli mayoritas konsumen berada pada persentase 54\%-60\%. Lebih dari setengah calon konsumen berminat untuk membeli produk ini, jumlah ini berkemungkinan meningkat jika cookies berhasil melakukan perubahan pada kekurangan-kekurangan produknya.

e. Positioning

Titik kesamaan (point of parity) dari sebuah cookies yang harus dipenuhi adalah sebagai berikut:

1) Cookies merupakan kue kering golongan soft dough dengan adonan yang tidak mengembang

2) Tekstur renyah

3) Memiliki bentuk dan ukuran yang sama atau terstandarisasi

4) Tahan lama jika disimpan di wadah kedap udara

5) Berfungsi sebagai cemilan, pendamping minuman, maupun hidangan perjamuan tamu. 
6) Rasa dominan manis

POP merupakan standar minimal yang harus dipenuhi oleh sebuah cookies. Selanjutnya agar cookies memiliki pembeda di ingatan konsumen perlu ditonjolkan titik perbedaan (point of difference) sebagai berikut:

1) Rasa cookies yang beredar saat ini didominasi oleh rasa coklat. Rasa kopi merupakan POD yang wajib ditonjolkan oleh cookies kopi. Konsep kopi yang biasanya diminum, dengan ini berganti menjadi kopi yang dikonsumsi dengan cara dikunyah dan bertekstrur renyah. Berdasarkan hal tersebut, dapat digunakan positioning statement "kopi renyah" atau "Crunchy Coffee".

2) Rasa cookies kopi dapat dikembangkan dengan tetap bertemakan kopi, seperti dikombinasikan dengan choco chip terasa seperti "mocca" (paduan kopi dan coklat), atau kombinasi kopi dan susu mengacu ke cappucino atau late.

3) Kemasan stand up pouch (berbahan plastik/aluminium/kertas) seperti kemasan bubuk/biji kopi premium, atau menyerupai gelas plastik kopi dapat digunakan oleh cookies kopi untuk mempertegas imej kopi di benak konsumen.

\subsection{Cookies Sorgum}

a. Kemasan Produk berbentuk kantong kertas coklat dengan plastik bening untuk memperlihatkan isi di dalam kemasan. Kemasan sudah dinilai bagus sebagai kemasan cookies kecil dengan rata-rata skor 7.4 (dari skala 10) dan mayoritas dinilai bagus secara estetika. Namun menurut calon konsumen, kemasan tersebut mudah rusak, basah, atau robek sehingga dapat mempengaruhi kualitas isi.

b. Harga produk Rp 5.000,-/ bungkus kecil. Calon konsumen dengan berbagai tingkat pendapatan berpendapat harga dan kuantitas produk sesuai serta tidak murah. Bagi calon konsumen yang menggunakan uang jajan mayoritas menganggap harga produk sesuai. Namun bagi calon konsumen di bawah kelas menengah, harga dirasakan agak mahal.

c. Cookies yang dibuat dari sorgum dinilai positif oleh calon konsumen, dengan mayoritas calon konsumen berpendapat rasa cookies ini enak dengan nilai akhir 7.3 dari skala 10. Calon konsumen laki-laki maupun perempuan memiliki pendapat yang hampir sama dimana mayoritas menilai rasa cookies sorgum enak. Melalui 
wawancara lebih lanjut, calon konsumen menilai rasa "enak, manisnya pas gurihnya pas". Penilaian tersebut muncul dari pengecapan rasa, tanpa mengetahui khasiat lebih lanjut dari produk tersebut. Setelah diedukasi bahwa produk ini dibuat dari sorgum (yang jenis komponen ini juga tidak dikenal oleh calon konsumen) yang gluten free cocok untuk diet, calon konsumen menilai positif "ternyata selain enak juga tidak perlu khawatir gula". Hal yang sama nantinya juga harus dilakukan oleh cookies sorgum yaitu mengedukasi konsumen tentang manfaat produk yang dapat ditampilkan di kemasan dan tagline.

d. Minat beli jika produk dikomersilkan nantinya. Jika mengacu pada bias dan toleransi jawaban konsumen sebesar 10\%, maka minat beli mayoritas konsumen berada pada persentase 59\%-64\%. Lebih dari setengah calon konsumen berminat untuk membeli produk ini, jumlah ini berkemungkinan meningkat jika cookies sorgum berhasil melakukan perubahan pada kekurangan-kekurangan produknya.

e. Positioning

Titik kesamaan (point of parity) dari sebuah cookies yang harus dipenuhi adalah sebagai berikut:

1) Cookies merupakan kue kering golongan soft dough dengan adonan yang tidak mengembang

2) Tekstur renyah

3) Memiliki bentuk dan ukuran yang sama atau terstandarisasi

4) Tahan lama jika disimpan di wadah kedap udara

5) Berfungsi sebagai cemilan, pendamping minuman, maupun hidangan perjamuan tamu.

6) Rasa dominan manis

POP merupakan standar minimal yang harus dipenuhi oleh sebuah cookies. Selanjutnya agar cookies memiliki pembeda di ingatan konsumen perlu ditonjolkan titik perbedaan (point of difference) sebagai berikut:

1) Sorgum sebagai bahan pokok memiliki berbagai kelebihan dibandingkan tepung lainnya. Sorgum yang gluten free baik untuk diet gluten dan konsumsi 
anak berkebutuhan khusus. Hal ini harus diinformasikan pada kemasan. Sehingga kata "sehat" atau "gluten free" merupakan pembeda produk ini dengan cookies lainnya.

2) Cookies sorgum dapat menggunakan positioning statement yang dapat berfungsi untuk menonjolkan "bebas gluten" dari sebuah cookies (yang identik dengan kaya gula), seperti: "Healthy Diet Cookies", "Healthy Crunchy", atau "Crunch to Your Health"

3) Untuk menunjang postitioning dibutuhkan tampilan kemasan yang menarik, dengan label menarik, dan informasi gizi/kesehatan yang jelas. Edukasi mengenai tumbuhan sorgum juga dapat dicantumkan pada kemasan dalam bentuk trivia atau informasi "tahukah anda manfaat sorgum". Kemasan berbahan plastik dengan label lebih memberi kesan "homey" dan "fresh" pada cookies yang handmade ini, sekaligus meningkatkan value sebagai cookies yang tidak diproduksi di pabrik.

\subsection{Crackers Daun Murbei}

a. Kemasan Produk berbentuk tabung dengan bahan mika bening. Kemasan sudah memenuhi standar kemasan dengan rata-rata skor 7.2 (dari skala 10) dan mayoritas dinilai bagus baik secara estetika maupun secara fungsi sebagai pelindung makanan. Calon konsumen menyarankan agar kemasan diberi label yang memuat manfaat produk dan daun murbei.

b. Calon konsumen diminta untuk menakar harga yang cocok untuk crackers dengan memperhatikan kemasan, kuantitas, dan rasa. Calon konsumen dengan berbagai tingkat pendapatan berpendapat harga yang cocok untuk produk ini berkisar antara Rp.,10.000,- hingga Rp. 15.000,-

c. Rasa crackers daun murbei dinilai netral oleh calon konsumen, dengan mayoritas calon konsumen berpendapat rasa cookies ini biasa dengan nilai akhir 6.2 dari skala 10. Melalui wawancara lebih lanjut, mayoritas calon konsumen menilai rasa terlalu flat/tawar, dan harapan calon konsumen produk ini sebaiknya berasa asin/gurin.

d. Minat beli jika produk dikomersilkan nantinya. Dengan penilaian terhadap merek, kemasan, rasa, dan harga saat ini mayoritas calon konsumen tidak berminat untuk membeli crackers bila dijual nantinya. Diperlukan perbaikan dari segi rasa dan kekurangan-kekurangan lainnya. Perlu dilakukan edukasi tentang manfaat daun 
murbei, hal ini dapat dimuat pada label, sehingga menambah value bagi konsumen yang membelinya. Walaupun produk ini memiliki berbagai khasiat, namun sebagai cemilan tetap dibutuhkan rasa yang enak, dan biasanya crackers memiliki rasa gurih/asin.

e. Positioning

Titik kesamaan (point of parity) dari sebuah cookies yang harus dipenuhi adalah sebagai berikut:

1) Crackers merupakan kue kering golongan hard dough yang diragikan dengan adonan yang tidak mengembang

2) Tekstur renyah

3) Memiliki bentuk dan ukuran yang sama atau terstandarisasi

4) Tahan lama jika disimpan di wadah kedap udara

5) Berfungsi sebagai cemilan, pendamping minuman, maupun hidangan perjamuan tamu.

6) Memiliki rasa bervariasi: asin maupun manis

POP merupakan standar minimal yang harus dipenuhi oleh sebuah crackers. Selanjutnya agar crackers memiliki pembeda di ingatan konsumen perlu ditonjolkan titik perbedaan (point of difference) sebagai berikut:

1) Manfaat crackers yang menggunakan daun murbei memiliki khasiat sebagai obat diabetes. Hal ini perlu ditampilkan pada kemasan atau tagline/positioning statement sehingga konsumen menyadari dan memahami manfaatnya selain sebagai cemilan.

2) Kemasan crackers sebaiknya dari bahan yang kedap dan tahan air sehingga dapat menjaga kerenyahan produk. Menggunakan kemasan plastik pouch dapat memberikan kesan higienis dan melindungi dengan baik. Contohnya:

3) Crackers dapat menggunakan positioning statement yang dapat berfungsi untuk menonjolkan manfaat kesehatan dari sebuah crackers, seperti: "Healthy Crackers", "Healthy Crunchy", atau "Crackers Sehat" dan ditambah dengan tagline "mengatasi diabetes" atau manfaat-manfaat lainnya. 


\subsection{Frozen Yoghurt}

a. Kemasan Produk berbentuk botol 250ml. Kemasan sudah memenuhi standar kemasan yoghurt dengan rata-rata skor 7.1 (dari skala 10) dan mayoritas dinilai bagus secara estetika maupun secara fungsi sebagai pelindung minuman. Calon konsumen menyarankan agar kemasan diberi label yang menarik dan keterangan produk.

b. Harga produk Rp 10.000,-/botol 250ml. Calon konsumen dengan berbagai tingkat pendapatan berpendapat harga dan kuantitas produk sesuai. $82 \%$ calon konsumen yang menggunakan uang jajan menganggap harga produk sesuai. Segmen konsumsi uang jajan ini terdiri dari mahasiswa/remaja.

c. Yoghurt dengan 3 varian rasa secara umum dinilai positif oleh calon konsumen, dengan mayoritas calon konsumen berpendapat rasa yoghurt ini enak dengan nilai akhir 7.5 dari skala 10. Rasa terenak pilihan konsumen adalah rasa mangga dengan nilai 7.7 dari skala 10, diikuti oleh rasa buah naga dan original.

d. Minat beli jika produk dikomersilkan nantinya. Mayoritas calon konsumen berminat untuk membeli Yoghurt bila dijual nantinya. Jika mengacu pada bias dan toleransi jawaban konsumen sebesar 10\%, maka minat beli mayoritas konsumen berada pada persentase $60 \%-67 \%$. Lebih dari setengah calon konsumen berminat untuk membeli produk ini, jumlah ini berkemungkinan meningkat jika Yoghurt berhasil melakukan perubahan pada kekurangan-kekurangan produknya.

e. Positioning

Titik kesamaan (point of parity) dari sebuah cookies yang harus dipenuhi adalah sebagai berikut:

1) Yoghurt adalah susu fermentasi dengan cita rasa asam

2) Disimpan di lemari pendingin

3) Sebaiknya dikonsumsi saat snacking time atau ketika perut kosong.

POP merupakan standar minimal yang harus dipenuhi oleh yoghurt. Selanjutnya agar yoghurt memiliki pembeda di ingatan konsumen perlu ditonjolkan titik perbedaan (point of difference) sebagai berikut:

1) Yoghurt rumahan membutuhkan pembeda dibandingkan yoghurt pabrikan. Imej utama yang harus ditonjolkan adalah "segar dan alami" karena dibuat 
dalam waktu yang berdekatan dengan waktu konsumsinya, bahan-bahan dari daerah setempat dan alami. Positioning statement yang dapat digunakan, seperti: "blended naturaly", sehat-segar-alami, dan "naturaly fresh"

2) Dari hasil survey di atas, yoghurt dengan rasa buah memiliki penggemar yang lebih banyak dibandingkan yang original. Ide memadukan segala kebaikan alam mulai dari susu dan buah segar perlu dilanjutkan dengan berbagai varian lainnya. Buah segar dapat membantu positioning statement diatas.

3) Memperkenalkan konsep "frozen yoghurt" sebagai yoghurt beku yang berbeda dari yoghurt pabrikan lainnya. Frozen yoghurt dapat dikonsumsi bersama buah segar.

4) Merek dan positioning statement dicantumkan di dalam label, beserta khasiat dan kandungannya.

\subsection{Kopi Kulit Manggis}

a. Kemasan Produk berbentuk kotak berisi 10 sachet tanpa gula. Kemasan sudah memenuhi standar kemasan kopi sachet dengan rata-rata skor 7.4 (dari skala 10) dan mayoritas dinilai bagus baik secara estetika maupun secara fungsi sebagai pelindung produk. Melalui wawancara lebih lanjut ditemui kesulitan dalam mengkonsumsi karena tidak disediakan gula langsung maupun yang terpisah dari sachet.

b. Harga produk Rp 20.000,-/kotak isi 20 kantong celup. Mayoritas calon konsumen dengan berbagai tingkat pendapatan berpendapat harga dan kuantitas produk sesuai serta tidak murah.

c. Rasa kopi dinilai positif oleh calon konsumen, dengan mayoritas calon konsumen berpendapat rasa kopi ini enak dengan nilai akhir 7.3 dari skala 10.

d. Minat beli jika produk dikomersilkan nantinya. Mayoritas calon konsumen berminat untuk membeli Kopi bila dijual nantinya. Jika mengacu pada bias dan toleransi jawaban konsumen sebesar 10\%, maka minat beli mayoritas konsumen berada pada persentase $63 \%-70 \%$.

e. Positioning

Titik kesamaan (point of parity) dari kopi sachet yang harus dipenuhi adalah sebagai berikut: 
1) Kopi praktis dikonsumsi, tinggal diseduh. Disediakan gula tercampur atau terpisah.

2) Memiliki citarasa pahit dan agak asam

3) Beraroma

POP merupakan standar minimal yang harus dipenuhi oleh kopi sachet. Untuk saat ini Kopi belum dilengkapi dengan gula/krimer. Selanjutnya agar kopi memiliki pembeda di ingatan konsumen perlu ditonjolkan titik perbedaan (point of difference) sebagai berikut:

1) Kulit manggis merupakan pembeda utama dari kopi ini dibandingkan kopikopi lainnya. Kulit manggis terasa lebih nikmat jika disajikan dalam bentuk kopi, dibandingkan bentuk kapsul dan lainnya.

2) Kulit manggis memiliki berbagai khasiat. Khasiat ini perlu dicantumkan di kotak Kopi.

3) Positioning statement yang dapat digunakan yaitu "healthy favor", "menyegarkan", "menyehatkan", "kopi sehat" mengacu pada khasiat yang dimiliki oleh kopi ini.

\subsection{Teh Kulit Manggis}

a. Kemasan Produk berbentuk kotak berisi 20 kantong celup. Kemasan sudah memenuhi standar kemasan teh celup dengan rata-rata skor 7.5 (dari skala 10) dan mayoritas dinilai bagus baik secara estetika maupun secara fungsi sebagai pelindung produk.

b. Harga produk Rp 25.000,-/kotak isi 20 kantong celup. Mayoritas calon konsumen dengan berbagai tingkat pendapatan berpendapat harga dan kuantitas produk sesuai serta tidak murah.

c. Teh dinilai positif oleh calon konsumen, dengan mayoritas calon konsumen berpendapat rasa teh ini enak dengan nilai akhir 7.5 dari skala 10.

d. Minat beli jika produk dikomersilkan nantinya. Mayoritas calon konsumen berminat untuk membeli Teh bila dijual nantinya. Jika mengacu pada bias dan toleransi jawaban konsumen sebesar 10\%, maka minat beli mayoritas konsumen berada pada persentase $69 \%-73 \%$.

e. Positioning 
Titik kesamaan (point of parity) dari sebuah teh yang harus dipenuhi adalah sebagai berikut:

1) Teh praktis dikonsumsi dengan kemasan kantong celup

2) Teh khas Indonesia berasa legit dan kental

3) Beraroma

POP merupakan standar minimal yang harus dipenuhi oleh the celup. Selanjutnya agar teh memiliki pembeda di ingatan konsumen perlu ditonjolkan titik perbedaan (point of difference) sebagai berikut:

1) Teh kulit manggis merupakan pembeda utama dari teh ini dibandingkan tehteh lainnya. Kulit manggis terasa lebih nikmat jika disajikan dalam bentuk the, dibandingkan bentuk kapsul dan lainnya.

2) Kulit manggis memiliki berbagai khasiat. Khasiat ini perlu dicantumkan di kotak teh.

3) Positioning statement yang dapat digunakan yaitu "menyegarkan", "menyehatkan" mengacu pada khasiat yang dimiliki oleh teh ini.

\subsection{Teh Daun Gambir}

a. Kemasan Produk berbentuk kotak berisi 25 kantong celup. kemasan sudah memenuhi standar kemasan the celup dengan rata-rata skor 7.5 (dari skala 10) dan mayoritas dinilai bagus baik secara estetika maupun secara fungsi sebagai pelindung produk.

b. Harga produk Rp 25.000,-/kotak isi 20 kantong celup. Mayoritas calon konsumen dengan berbagai tingkat pendapatan berpendapat harga dan kuantitas produk sesuai serta tidak murah.

c. Rasa Teh Gambir dinilai positif oleh calon konsumen, dengan mayoritas calon konsumen berpendapat rasa teh ini enak dengan nilai akhir 7.5 dari skala 10. Melalui wawancara lebih lanjut, calon konsumen menilai rasanya agak kelat dibandingkan teh biasa.

d. Minat beli jika produk dikomersilkan nantinya. Mayoritas calon konsumen berminat untuk membeli Teh bila dijual nantinya. Jika mengacu pada bias dan toleransi jawaban konsumen sebesar 10\%, maka minat beli mayoritas konsumen berada pada persentase $66 \%-73 \%$. 
e. Minat beli jika produk dijual secara online. Jika produk dijual secara online maka minat beli hanya di angka $41 \%$. Hal ini disebabkan oleh perilaku konsumsi, dimana biasanya konsumen membeli produk convenience goods seperti kopi, teh, dan lainnya secara langsung di ritel-ritel terdekat yang mudah dijangkau. Karena produk ini dibutuhkan segera dan menghindari waktu tunggu (jika dibeli secara oline membutuhkan waktu pengantaran). Produk seperti ini mengutamakan ketersediaan produk di berbagai saluran penjualan terdekat dari rumah konsumen.

f. Positioning

Titik kesamaan (point of parity) dari sebuah teh yang harus dipenuhi adalah sebagai berikut:

1) Teh praktis dikonsumsi dengan kemasan kantong celup

2) The khas Indonesia berasa legit dan kental

3) Beraroma

POP merupakan standar minimal yang harus dipenuhi oleh the celup. Selanjutnya agar teh memiliki pembeda di ingatan konsumen perlu ditonjolkan titik perbedaan (point of difference) sebagai berikut:

1) Teh daun gambir merupakan pembeda utama dari teh ini dibandingkan tehthe lainnya.

2) Daun gambir memiliki khasiat untuk menjaga stamuna, mencegah berbagai penyakit akibat radikal bebas, dan lainnya. Khasiat ini sudah tercantum di kotak teh.

3) Positioning statement yang digunakan saat ini " minuman sehat dari daun gambir pilihan" sudah memenuhi imej yang ingin ditonjolkan yaitu "gambir berkualitas/pilihan" dan "sehat" yang mewakili berbagai khasiat penyembuhan yang dimiliki oleh teh ini.

\section{KESIMPULAN DAN IMPLIKASI}

a. Calon konsumen memiliki penilaian yang baik terhadap merek, kemasan, rasa, dan harga pada produk inovasi. Mayoritas calon konsumen berminat untuk membeli 
produk inovasi bila dijual nantinya, dan kemungkinan pembelian akan meningkat jika melakukan perbaikan pada kekurangan-kekurangan produknya.

b. Produk inovasi memiliki positioning beragam di benak konsumen. Diperlukan pemahaman dan penerapan POP dan POD lebih lanjut. POP merupakan standar minimal yang harus dipenuhi oleh sebuah produk. Selanjutnya agar memiliki pembeda di ingatan konsumen perlu ditonjolkan titik POD.

\section{REFERENSI}

Games, D. 2019, “Can SME Bennefit from Innovation”, Academy of Entrepreneurship Journal, 25 (1).

Griffin, R.W. and Pustay, M.W. 2014, International Business: A Managerial Perspective $8^{\text {th }}$ edition. Pearson

Kartajaya, H. 2011. Hermawan Kartajaya on Marketing, Gramedia, Jakarta

Kotler, P. and Keler, K.L. 2016, Marketing Management 15th edition. Pearson Prentice Hall, New Jersey

Kotler, P and Amstrong, G. 2018, Principles of Marketing, 17th edition, International Edition, Prentice Hall, New Jersey

Kotler, P. and Amstrong, G. 2003, Marketing, An Introduction $6^{\text {th }}$ edition, Prentice Hall

Maholtra, N. and Birks, D. 2007, Marketing Research: An Applied Orientation $3^{\text {rd }}$ edition, Pearson Education

Schiffman, L. and Kanuk, L. 2015, Consumer Behavior 11 th edition, Global Edition. Pearson

Trout, P. 2005, Innovation Management and New Product Development, Pearson Education Limited 